\title{
Responses of antioxidant enzymes, photosynthetic pigments and carbohydrates in micropropagated Pitcairnia encholirioides L.B. Sm. (Bromeliaceae) under ex vitro water deficit and after rehydration
}

\author{
C. F. Resende ${ }^{a *}$, V. S. Pacheco ${ }^{a}$, F. F. Dornellas ${ }^{a}$, A. M. S. Oliveira ${ }^{a}$, J. C. E. Freitas ${ }^{a}$ \\ and P. H. P. Peixoto ${ }^{a}$
}

a'Laboratório de Fisiologia Vegetal, Departamento de Botânica, Instituto de Ciências Biológicas, Universidade Federal de Juiz de Fora - UFJF, Campus Universitário, Bairro Martelos, CEP 36036-900, Juiz de Fora, MG, Brasil

*e-mail: cristianoig2004@hotmail.com

Received: February 2, 2017 - Accepted: August 3, 2017 - Distributed: February 28, 2019

(With 1 figure)

\begin{abstract}
In this study, the activities of antioxidant enzymes, photosynthetic pigments, proline and carbohydrate contents in Pitcairnia encholirioides under ex vitro conditions of water deficit were evaluated. Results show that plants under progressive water stress, previously in vitro cultured in media supplemented with $30 \mathrm{~g} \mathrm{~L}^{-1}$ sucrose and GA, accumulated more proline and increased peroxidase (POD) activity and the contents of photosynthetic pigments and carbohydrates. For plants previously in vitro cultured with $15 \mathrm{~g} \mathrm{~L}^{-1}$ sucrose and NAA, no differences were found for proline content and there were reductions in activities of peroxidase (POD), catalase (CAT) and poliphenoloxidase (PPO), and in contents of carbohydrates, with progress of ex vitro water deficit. After rehydration, plants showed physiological recovery, with enzymatic activities and contents of metabolites similar to those found in the controls not submitted to dehydration, regardless of the previous in vitro culture conditions. These results show that micropropagated $P$. encholirioides has high tolerance to dehydration once in ex vitro conditions, which can ensure the survival of plants from tissue culture when transferred to its natural environment, emphasizing the importance of such biotechnology for the propagation of endangered species.
\end{abstract}

Keywords: antioxidant enzymes, carbohydrates, photosynthetic pigments, proline, water stress.

\section{Respostas de enzimas antioxidantes, pigmentos fotossintéticos e carboidratos em Pitcairnia encholirioides L.B. Sm. (Bromeliaceae) micropropagadas, sob déficit hídrico ex vitro e após reidratação}

\begin{abstract}
Resumo
Neste estudo, foram avaliadas as atividades de enzimas antioxidantes, pigmentos fotossintéticos, conteúdo de prolina e carboidratos em Pitcairnia encholirioides sob déficit hídrico em condições ex vitro. Os resultados mostraram que as plantas sob estresse hídrico progressivo, previamente cultivadas in vitro em meio de cultura suplementado com $30 \mathrm{~g} \mathrm{~L}^{-1}$ de sacarose e $\mathrm{GA}_{3}$ acumularam mais prolina e aumentaram a atividade da peroxidase (POD) e os teores de pigmentos fotossintéticos e carboidratos. Para plantas previamente cultivadas in vitro com $15 \mathrm{~g} \mathrm{~L}^{-1}$ de sacarose e ANA, não foram encontradas diferenças nos conteúdos de prolina e houve reduções nas atividades da peroxidase (POD), catalase (CAT) e polifenoloxidase (PPO), e no conteúdo de carboidratos, com o progresso do déficit hídrico ex vitro. Após a reidratação, as plantas apresentaram recuperação fisiológica, com atividades enzimáticas e conteúdo de metabólitos semelhantes aos encontrados nos controles não sujeitos à desidratação, independentemente das condições de cultivo in vitro. Estes resultados mostram que $P$. encholirioides micropropagada tem alta tolerância à desidratação uma vez em condições ex vitro, o que pode garantir a sobrevivência de plantas provenientes da cultura de tecidos quando transferidas para seu ambiente natural, enfatizando a importância desta biotecnologia para a propagação de espécies ameaçadas.
\end{abstract}

Palavras-chave: enzimas antioxidativas, carboidratos, pigmentos fotossintéticos, prolina, estresse hídrico.

\section{Introduction}

The Bromeliaceae family is composed of 69 genera and 3629 species (Gouda and Butcher, 2016). Its species occur in a wide range of habitats, resulting in a large diversity of plants shapes and life forms (Vanhoutte et al., 2016). Within the last few decades, due to their beautiful shapes, bracts and flowers with vivid and contrasting colors, 
bromeliads have become widely used as ornamental plants (Negrelle et al., 2012; Souza et al., 2016).

The Atlantic Forest is one of the major centers of diversity for Bromeliaceae, holding ca. 900 species (Alves et al., 2015). Such bromeliads have restricted distributions, reduced populations and high specificity of habitats, factors that, together with the accelerated loss of native vegetation and exacerbated extractivism, are responsible for the decrease of natural populations and have pushed numerous species close to extinction (Pereira et al., 2008; Forzza et al., 2013).

Pitcairnia encholirioides L.B. Sm. is a very rare species, collected in 1934 and described by Smith in 1950 from a single specimen constituted by inflorescence only (Martinelli and Forzza, 2006). This species is endemic to Brazil, occurring exclusively in Santa Maria Madalena, in the State of Rio de Janeiro. Only two subpopulations are known, the largest being composed of around 900 individuals and subjected to fire and trampling by animals (Forzza et al., 2013). This species was included in the critically endangered category by the Biodiversitas Foundation (2005) and, more recently, as an endangered species in the Red Book of Brazilian Flora (Forzza et al., 2013).

Tissue culture is a very important alternative for germplasm conservation of bromeliads to ensure high multiplication rates, allowing the commercial production and providing plants for reintroduction, which is especially important for species at risk of extinction (Dal Vesco et al., 2011; Resende et al., 2016a). However, during in vitro cultivation, the seedlings grow under different conditions than those of the field, such as high air humidity, low light intensity, carbon source as the glucose or sucrose addition and $\mathrm{CO}_{2}$ concentration in the culture vessel often insufficient to the photosynthetic process (Pospíšilová et al., 2007). Different strategies can be used to produce in vitro plants able to support the acclimatization stage, the final and critical step that represents a limiting factor for the success of the micropropagation system (Chandra et al., 2010; Hong et al., 2016). The presence of a sealing system that allows gas exchanges with the external environment, increasing the concentration of $\mathrm{CO}_{2}$ and reducing the air relative humidity in the culture vessel, the exposure to a higher light intensity and the decrease of the sugar content in the culture medium are factors that can promote the photoautotrophic or mixotrophic growth of plants, leading them to maximize the ex vitro survival rates (Xiao et al., 2011; Sáez et al., 2016).

Under field conditions, plants can suffer water deficit, with the reduction of relative water content and leaf water potential, progressive closing of the stomata and reduction of the transpiration rate and $\mathrm{CO}_{2}$ assimilation. These changes may promote increase in generation of reactive oxygen species (ROS), leading to lipid peroxidation and other metabolic disorders (Reddy et al., 2004; Noctor et al., 2014; Ebrahimi et al., 2016).

Among the antioxidant enzymes acting as one of the main mechanisms of tolerance against oxidative stress in plants are the superoxide dismutase (SOD), catalase
(CAT), and peroxidase (POD) (Liu et al., 2015). Other physiological and biochemical processes are activated in response to water stress and drought, including the production and/or accumulation of compatible solutes (Hoekstra et al., 2001; Foster et al., 2015). Proline is one of the most important osmoprotectants, possessing fundamental importance for the adjustment and tolerance of plants to abiotic stresses (Molinari et al., 2007; Sharma et al., 2011). Carbohydrates are another group of molecules stored in response to water stress, contributing to osmotic adjustment and plants tolerance to desiccation (Mohammadkhani and Heidari, 2008; Dinakar et al., 2012; Velázquez-Márquez et al., 2015). The accumulation of compatible solutes, like sugars and amino acids, increases the cellular osmotic pressure, regulates the osmotic balance between the vacuole and the cytosol, maintains the turgor pressure and water content of cells, and protects against water loss from plants because of their high lipophilicity (Salehi-Lisar and Bakhshayeshan-Agdam, 2016).

Chlorophylls are essential components of the photosynthetic apparatus, can be used as a plant hardening indicator after acclimatization (Gour et al., 2007), and its content can be negatively affected in situations of water stress. In these conditions, in which oxidative stress can occur, carotenoids also cooperate in the non-enzymatic antioxidant defense system as ROS scavenger (Pospíšilová et al., 2009; Liu et al., 2011).

Several works in the literature address the biochemical changes that occur in plants in response to water stress. The majority of those works utilizes species of economic importance in order to identify the mechanisms by which they react to drought and select more tolerant plants (Carvalho, 2008; Furlan et al., 2016). However, few papers address endangered species. To our knowledge, there are no reports of works with bromeliads at threat of extinction previously in vitro cultured. The objective of this study was to investigate the activities of antioxidant enzymes, proline, carbohydrates and photosynthetic pigments accumulation in leaves of micropropagated $P$. encholirioides subjected to water stress and after rehydration, in order to increase the survival of this species in ex vitro conditions. This work complements the data obtained by our research group with $P$. encholirioides in vitro and under acclimatization (Resende et al., 2016b), the only work in literature, to our knowledge, that addresses physiological traits of this species.

\section{Material and Methods}

\subsection{Plant material and in vitro culture conditions}

Cultures of Pitcairnia encholirioides L.B. Sm. were previously established in vitro from seeds collected in the natural environment in Santa Maria Madalena, Rio de Janeiro State, Brazil. Conditions of in vitro and acclimatization phases performed here were described by Resende et al. (2016b). The seedlings grew in test tubes $(2.5 \times 15 \mathrm{~cm})$ filled with MS basal medium (Murashige and Skoog, 1962) supplemented with $10 \mu \mathrm{M}$ gibberellic acid $\left(\mathrm{GA}_{3}\right)$ or $0.2 \mu \mathrm{M} \alpha$-naphthalene-acetic acid (NAA), and 
sucrose at 15 or $30 \mathrm{~g} \mathrm{~L}^{-1}$, with $7 \mathrm{~g} \mathrm{~L}^{-1}$ agar, in all possible combinations. The plants were kept for 150 days in a growth chamber under controlled conditions of temperature $\left(26 \pm 1{ }^{\circ} \mathrm{C}\right)$, photoperiod $(16-8 \mathrm{~h})$ and irradiance $(40 \mu \mathrm{mol}$ photons $\mathrm{m}^{-2} \mathrm{~s}^{-1}$ ). Then, plants were subjected to ex vitro acclimatization, being transplanted to polystyrene trays of 128 cells, filled with Plantmax Hortaliças HT $\left(\right.$ Eucatex $\left.^{\circledR}\right)$, and kept for another 180 days in a greenhouse, with near $100 \%$ humidity, temperature of $27 \pm 3{ }^{\circ} \mathrm{C}$, under shade (Sombrite ${ }^{\circledR} 75 \%, 150-200 \mu \mathrm{mol}$ photons $\mathrm{m}^{-2} \mathrm{~s}^{-1}$ ). After this period, treatments that obtained the highest growth rate, with the production of new leaves for the biochemical tests, were selected. Plants from treatments with $10 \mu \mathrm{M} \mathrm{GA}_{3}$ plus $30 \mathrm{~g} \mathrm{~L}^{-1}$ sucrose and $0.2 \mu \mathrm{M}$ NAA plus $15 \mathrm{~g} \mathrm{~L}^{-1}$ sucrose were subjected to a progressive dehydration. Irrigation suppression for each group started at 30,42, and 54 days before biochemical analyses, in addition to a control group irrigated every day during the same period. After this water stress period, all the plants were rehydrated and kept for 90 days in greenhouse with the same acclimatization conditions.

\subsection{Biochemical analyses}

After the drought period and 90 days after rehydration, nine plants of each treatment were used in biochemical analyses.

In order to determine the contents of proline, $0.3 \mathrm{~g}$ of fresh leaf was powdered in liquid $\mathrm{N}_{2}$, followed by addition of $10 \mathrm{~mL}$ of sulfosalicylic acid at 3\%(w/v) and by purification through Whatman $\mathrm{N}^{\mathrm{o}} 2$ filter. The proline content was determined according to Bates et al. (1973), using absorbance reading in a spectrophotometer at $520 \mathrm{~nm}$.

For photosynthetic pigments analysis, $0.1 \mathrm{~g}$ of fresh leaf was powdered in liquid $\mathrm{N}_{2}$. Then, $25 \mathrm{~mL}$ of $80 \%$ acetone $(\mathrm{v} / \mathrm{v})$ were added, followed by filtration. The contents of photosynthetic pigments were estimated using absorbance readings at 663, 647 and $470 \mathrm{~nm}$ for the calculations, according to Equations 1-4 described by Lichtenthaler (1987):

$$
\begin{aligned}
& \text { Chl } a=12.25 A_{664}-2.79 A_{647} \\
& \text { Chl } b=21.50 A_{647}-5.10 A_{664} \\
& \text { Chl } a+b=7.15 A_{664}+18.71 A_{647} \\
& \text { Carot }=\frac{1,000 A_{470}-1.82 C h l_{a}-85.02 C h l_{b}}{198}
\end{aligned}
$$

The extracts for determination of total protein content and antioxidant enzyme activities were obtained by powdering $0.3 \mathrm{~g}$ of fresh leaf in liquid $\mathrm{N}_{2}$, followed by addition of $10 \mathrm{~mL}$ of potassium phosphate buffer [0.1 M, pH 6.8, EDTA $0.1 \mathrm{mM}$ and PMSF $1 \mathrm{mM}$ ], filtration through four layers of cheesecloth and centrifugation at $10,000 \mathrm{~g}$ for $15 \mathrm{~min}$ at $4{ }^{\circ} \mathrm{C}$. The protein contents were evaluated according to Lowry et al. (1951), modified. The reagents used were: A, consisting of $0.5 \%(\mathrm{w} / \mathrm{v}) \mathrm{CuSO}_{4} \cdot 5 \mathrm{H}_{2} \mathrm{O}$ in $1 \%(\mathrm{w} / \mathrm{v})$ sodium citrate and $\mathbf{B}, 2 \%(\mathrm{w} / \mathrm{v}) \mathrm{Na}_{2} \mathrm{CO}_{3}$ in $\mathrm{NaOH} 0.1 \mathrm{~N}$. Reagent
C was prepared by mixing the $50: 1(\mathrm{v} / \mathrm{v})$ ratio of reagents $\mathbf{B}$ and $\mathbf{A}$, respectively. Reagent $\mathbf{D}$ was composed of the folin-Ciocauteau phenol reagent, diluted 50\% (v/v) in distilled water. After preparation of the reagents, $100 \mu \mathrm{L}$ of crude enzyme extract plus $2.5 \mathrm{~mL}$ of reagent $\mathbf{C}$ were used. After stirring, the mixture stood at room temperature for $10 \mathrm{~min}$. Then, $0.25 \mathrm{~mL}$ of reagent $\mathbf{D}$ was added, the mixture was vortexed and stood at room temperature for $30 \mathrm{~min}$. The absorbance was read in a spectrophotometer at $735 \mathrm{~nm}$, with the protein content being determined by a calibration curve, using $1 \mathrm{mg} \mathrm{mL}^{-1} \mathrm{BSA}$ (bovine serum albumin) as standard.

SOD activity was measured according to Del Longo et al. (1993). The reaction mixture consisted of $13 \mathrm{mM}$ methionine, $75 \mu \mathrm{M}$ p-nitro blue tetrazolium (NBT), $100 \mathrm{nM}$ EDTA and $2 \mu \mathrm{M}$ riboflavin, in $50 \mathrm{mM}$ sodium phosphate buffer, $\mathrm{pH}$ 7.8. $100 \mathrm{~mL}$ of the crude enzyme extract were used. The enzyme catalysis was carried out in a chamber illuminated by a $15 \mathrm{~W}$ fluorescent lamp for $3 \mathrm{~min}$. Photoreduction of nitroblue tetrazolium (NBT) to blue formazan was assessed by the increase of absorbance at $560 \mathrm{~nm}$. One unit (U) of SOD activity was defined as the quantity of enzyme necessary to inhibit the NBT reduction by $50 \%$.

POD and polyphenoloxidase (PPO) activities were measured according to Kar and Mishra (1976). $100 \mu \mathrm{L}$ of the crude enzyme extract were added to $4.9 \mathrm{~mL}$ of a reaction mixture containing: $25 \mathrm{mM}$ potassium phosphate buffer, $\mathrm{pH}$ 6.8, $20 \mathrm{mM}$ pyrogallol and $20 \mathrm{mM} \mathrm{H}_{2} \mathrm{O}_{2}$ (excluded from the PPO incubation medium, in which distilled water was used). After incubation of the solution for one min at $25^{\circ} \mathrm{C}$, the reaction was stopped by the addition of $0.5 \mathrm{~mL}$ of $5 \%(\mathrm{v} / \mathrm{v}) \mathrm{H}_{2} \mathrm{SO}_{4}$. The absorbance of the solution was read at $420 \mathrm{~nm}$ against the control, in which the enzyme was previously inactivated by the addition of $0.5 \mathrm{ml}$ of $5 \%(\mathrm{v} / \mathrm{v}) \mathrm{H}_{2} \mathrm{SO}_{4}$. The enzyme activity was calculated using a molar extinction coefficient of $2.47 \mathrm{mM}^{-1} \mathrm{~cm}^{-1}$.

CAT activity was measured according to Havir and McHale (1987) by the monitoring of absorbance decrease at $240 \mathrm{~nm}$, assuming a molar extinction coefficient of $36 \mathrm{M}^{-1} \mathrm{~cm}^{-1}$, in a reaction medium consisting of $12.5 \mathrm{mM} \mathrm{H}_{2} \mathrm{O}_{2}$



Sucrose content was determined according to Van Handel (1968). $0.1 \mathrm{~g}$ of fresh leaf was powdered in liquid $\mathrm{N}_{2}$, homogenized in $1.5 \mathrm{~mL}$ of the MCA mixture (methanol, chloroform and water; $12: 5: 3 \mathrm{v} / \mathrm{v} / \mathrm{v}$ ) and centrifuged at $3,500 \mathrm{~g}$ for $30 \mathrm{~min}$ at $4{ }^{\circ} \mathrm{C}$. The sucrose content was estimated at $620 \mathrm{~nm}$ from a sucrose standard curve. The content of total soluble sugars (TSS) was determined according to Dubois et al. (1956). $0.1 \mathrm{~g}$ of fresh leaf was powdered in liquid $\mathrm{N}_{2}$, placed in $15 \mathrm{~mL}$ test tubes, homogenized with $5 \mathrm{~mL}$ of distilled water and transferred to a water bath for $30 \mathrm{~min}$ at $100{ }^{\circ} \mathrm{C}$. Then, the tubes were centrifuged at $1,900 \mathrm{~g}$ for $10 \mathrm{~min}$ and the extracts were added of $0.5 \mathrm{~mL}$ phenol $5 \%(\mathrm{~m} / \mathrm{v})$ and $2.5 \mathrm{~mL}$ sulfuric acid. The absorbance was read at $490 \mathrm{~nm}$ and the TSS content was estimated using a glucose standard curve. The starch content was also determined according to Dubois et al. (1956). Samples 
of $0.1 \mathrm{~g}$ fresh leaf were maintained in $5 \mathrm{~mL}$ of $80 \%(\mathrm{v} / \mathrm{v})$ ethanol for $30 \mathrm{~min}$ at $80^{\circ} \mathrm{C}$ and then extracted with $5.0 \mathrm{~mL}$ of perchloric acid $\left(\mathrm{HClO}_{4}\right) 30 \%(\mathrm{v} / \mathrm{v})$ for $30 \mathrm{~min}$ at $25^{\circ} \mathrm{C}$, followed by centrifugation at $3,500 \mathrm{~g}$. Starch content was determined at $490 \mathrm{~nm}$ using a glucose standard curve. The reducing sugars (RS) content was calculated by the difference between TSS and sucrose contents.

All the analyses were carried out in a completely randomized design (CRD) with two treatments (plants previously in vitro cultured with $15 \mathrm{~g} \mathrm{~L}^{-1}$ sucrose plus NAA and plants previously in vitro cultured with $30 \mathrm{~g} \mathrm{~L}^{-1}$ sucrose plus $\mathrm{GA}_{3}$ ). The data were processed and analyzed using ANOVA one-way and the means of different periods of dehydration for both treatments were compared by the Scott-Knott test at 5\% probability using the SAEG software (System for Statistical Analysis, version 9.1, UFV, Brazil).

\section{Results}

In the acclimatization phase, the plantlets showed an appropriate morphological development and reduced death rate (less than $2 \%$ ) regardless of their in vitro source (Figure 1A-B). Plantlets from both treatments showed similar morphological development both during dehydration (Figure 1C-J) and after rehydration, with the recovery of turgor regardless of the in vitro origin (Figure $1 \mathrm{~K}-\mathrm{L}$ ). However, a quantitative analysis detected differences in plant responses coming from the two evaluated conditions.
In materials submitted to dehydration, a significant increase in proline accumulation was found only in plants previously maintained in culture media containing $30 \mathrm{~g} \mathrm{~L}^{-1}$ sucrose and $\mathrm{GA}_{3}$ (Table 1). After 90 days of rehydration, the proline content in plants previously subjected to dehydration was similar to the control, regardless of the source of the material (Table 2). There was a reduction of proline content in leaves that had accumulated high amounts of this amino acid in response to water stress.

Regardless of the water deprivation period, plants from culture media supplemented with $30 \mathrm{~g} \mathrm{~L}^{-1}$ sucrose and $\mathrm{GA}_{3}$ presented a significant reduction in SOD activity when compared to the control (Table 1), reaching $36.8 \%$ at the end of the stress. Regarding CAT activity, significant effects were observed only in plants previously in vitro cultured with $15 \mathrm{~g} \mathrm{~L}^{-1}$ sucrose and NAA after 30 days of dehydration, with $36.7 \%$ of reduction compared to the control, with the activity remaining statistically unchanged until the last day of stress imposition. The POD activity showed a typical behavior when both plant sources were compared. An increase of $258 \%$ in the enzymatic activity until $42 \mathrm{~d}$ of dehydration was observed in plants from culture media supplemented with $30 \mathrm{~g} \mathrm{~L}^{-1}$ sucrose and $\mathrm{GA}_{3}$ when compared to control and no change was found following this period. However, in plants from the other treatment, there was a reduction of $25.3 \%$ in the POD activity after the 30th day of water stress, remaining at that level until the last analysis. The PPO activity decreased in response to the increasing period of dehydration, although this
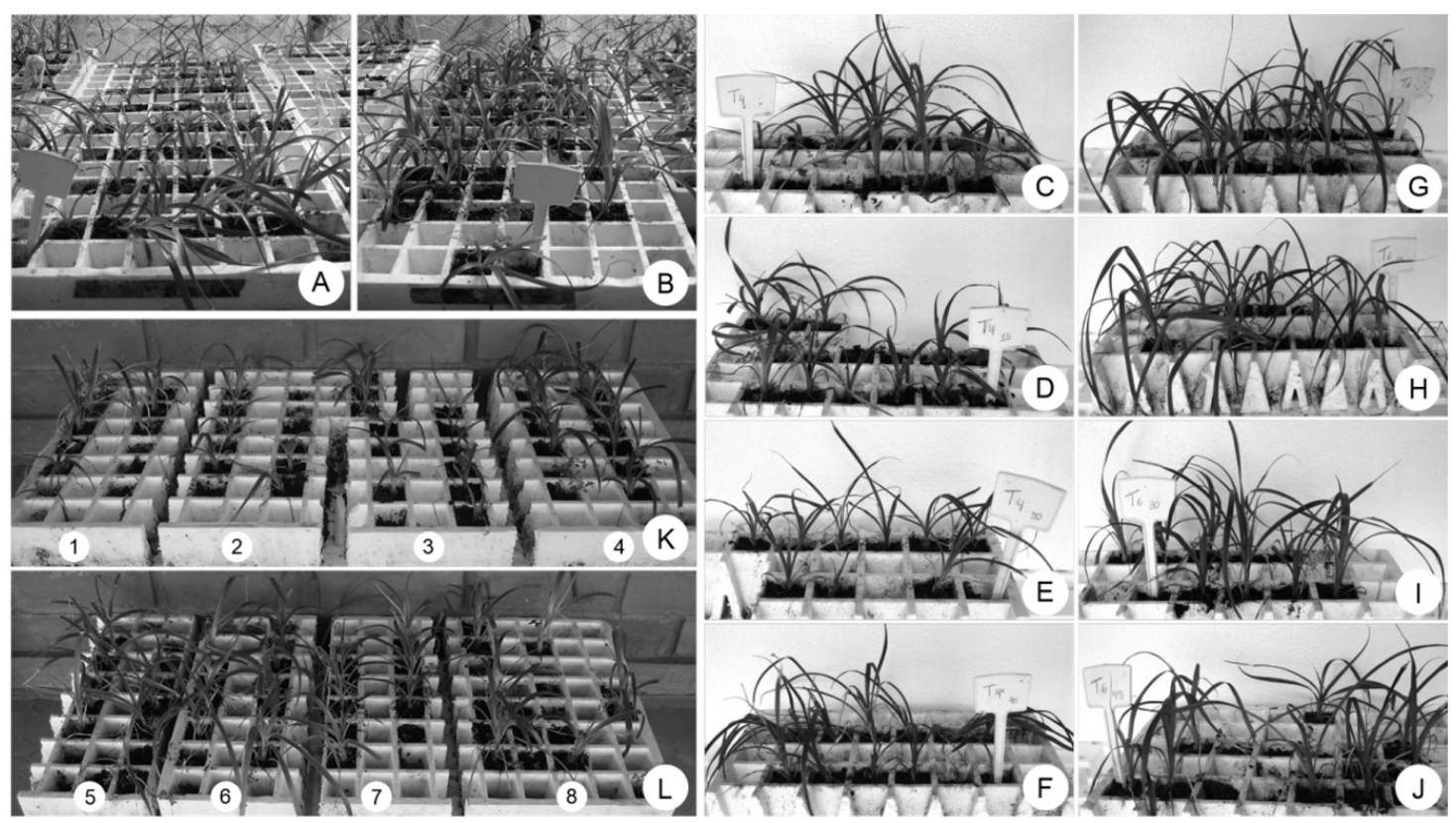

Figure 1. Detail of plants of Pitcairnia encholirioides. A-B - Four months after acclimatization, in a greenhouse. Treatments: $\mathrm{A}-10 \mu \mathrm{M} \mathrm{GA}_{3}$ and $30 \mathrm{~g} \mathrm{~L}^{-1}$ sucrose; $\mathrm{B}-0.2 \mu \mathrm{M}$ NAA and $15 \mathrm{~g} \mathrm{~L}^{-1}$ sucrose. C-J - Under progressive dehydration. C to F correspond to plants derived from in vitro treatments with $10 \mu \mathrm{M} \mathrm{GA}_{3}$ and $30 \mathrm{~g} \mathrm{~L}^{-1}$ sucrose and $\mathrm{G}$ to $\mathrm{J}$, plants grown in medium with $0.2 \mu \mathrm{M}$ NAA and $15 \mathrm{~g} \mathrm{~L}^{-1}$ sucrose. Treatments: $\mathrm{C}$ and $\mathrm{G}$ - controls, irrigated periodically; D and $\mathrm{H}$ - 30 days of dehydration; E and I - 42 days of dehydration; F and J - 54 days of dehydration. K-L - After 90 days of re-watering. K (1 to 4 ) corresponds to C-F and L ( 5 to 8 ) corresponds to G-J. Each cell of the polystyrene trays has $3.5 \times 3.5 \mathrm{~cm}$. 
reduction was more prominent in plants previously in vitro cultured in the presence of $15 \mathrm{~g} \mathrm{~L}^{-1}$ sucrose and NAA. After rehydration of $P$. encholirioides plants, there were no differences in enzymatic activity between the materials submitted to dehydration and the control (Table 2), regardless of the period of dehydration and the origin of the plants.
Regarding chlorophyll $a(\mathrm{Chl} a)$, chlorophyll $b(\mathrm{Chl} b)$, total chlorophyll (Chl $a+b)$ and total carotenoids (Carot), we found, on average, approximately $150 \%$ of increases in the content of these pigments in response to extension of the dehydration period in plants cultured in vitro in the presence of the higher concentrations of sucrose and GA

Table 1. Total proteins $\left[\mathrm{mg} \mathrm{g}^{-1}\right.$ (f.m.) $]$ and proline $\left[\mu \mathrm{mol} \mathrm{g}^{-1}\right.$ (f.m.) $]$ contents, and SOD $\left[\mathrm{U} \mathrm{mg}^{-1}\right.$ (prot.)], CAT [ $\mathrm{mmol} \mathrm{mg}^{-1}$ (prot.) $\mathrm{min}^{-1}$ ], POD $\left[\mu \mathrm{mol} \mathrm{mg} \mathrm{m}^{-1}\right.$ (prot.) $\left.\mathrm{min}^{-1}\right]$ and PPO $\left[\mu \mathrm{mol} \mathrm{mg}^{-1}\right.$ (prot.) $\left.\mathrm{min}^{-1}\right]$ activities in leaves of Pitcairnia encholirioides after $0,30,42$ or 54 days of dehydration, from in vitro cultivation in presence of $\mathrm{GA}_{3}$ and $30 \mathrm{~g} \mathrm{~L}^{-1}$ sucrose or NAA and $15 \mathrm{~g} \mathrm{~L}^{-1}$ sucrose. Mean \pm standard error, $\mathrm{n}=9$.

\begin{tabular}{cccccccc}
\hline \multicolumn{2}{c}{ Treatment } & Total proteins & Proline & SOD & CAT & POD & PPO \\
\hline $\mathrm{GA}_{3}$ & 0 & $0.097 \pm 0.004 \mathrm{~B}$ & $0.97 \pm 0.09 \mathrm{~B}$ & $261.8 \pm 25.7 \mathrm{~A}$ & $1.45 \pm 0.05 \mathrm{~A}$ & $70.2 \pm 6.3 \mathrm{C}$ & $34.2 \pm 1.5 \mathrm{~A}$ \\
$30 \mathrm{~g} \mathrm{~L}^{-1}$ & 30 & $0.106 \pm 0.003 \mathrm{~B}$ & $1.21 \pm 0.12 \mathrm{~B}$ & $201.7 \pm 14.5 \mathrm{~B}$ & $1.46 \pm 0.07 \mathrm{~A}$ & $115.1 \pm 3.6 \mathrm{~B}$ & $35.9 \pm 2.1 \mathrm{~A}$ \\
& 42 & $0.218 \pm 0.005 \mathrm{~A}$ & $1.48 \pm 0.05 \mathrm{~A}$ & $168.7 \pm 16.3 \mathrm{~B}$ & $1.49 \pm 0.01 \mathrm{~A}$ & $251.3 \pm 6.9 \mathrm{~A}$ & $31.4 \pm 0.6 \mathrm{~B}$ \\
& 54 & $0.220 \pm 0.004 \mathrm{~A}$ & $1.58 \pm 0.27 \mathrm{~A}$ & $165.5 \pm 12.0 \mathrm{~B}$ & $1.48 \pm 0.03 \mathrm{~A}$ & $258.3 \pm 12.8 \mathrm{~A}$ & $29.8 \pm 0.6 \mathrm{~B}$ \\
$\mathrm{NAA}$ & 0 & $0.085 \pm 0.003 \mathrm{C}$ & $0.96 \pm 0.20 \mathrm{~A}$ & $141.2 \pm 18.1 \mathrm{~A}$ & $3.05 \pm 0.02 \mathrm{~A}$ & $217.2 \pm 5.9 \mathrm{~A}$ & $49.5 \pm 1.4 \mathrm{~A}$ \\
$15 \mathrm{~g} \mathrm{~L}^{-1}$ & 30 & $0.146 \pm 0.001 \mathrm{~B}$ & $1.11 \pm 0.13 \mathrm{~A}$ & $114.2 \pm 9.8 \mathrm{~A}$ & $1.93 \pm 0.08 \mathrm{~B}$ & $223.3 \pm 8.6 \mathrm{~A}$ & $39.0 \pm 2.9 \mathrm{~B}$ \\
& 42 & $0.142 \pm 0.003 \mathrm{~B}$ & $1.20 \pm 0.17 \mathrm{~A}$ & $117.1 \pm 6.5 \mathrm{~A}$ & $1.80 \pm 0.08 \mathrm{~B}$ & $161.9 \pm 4.0 \mathrm{~B}$ & $34.4 \pm 1.5 \mathrm{~B}$ \\
& 54 & $0.198 \pm 0.009 \mathrm{~A}$ & $1.17 \pm 0.05 \mathrm{~A}$ & $115.8 \pm 8.4 \mathrm{~A}$ & $1.72 \pm 0.16 \mathrm{~B}$ & $167.1 \pm 9.3 \mathrm{~B}$ & $27.1 \pm 0.7 \mathrm{C}$ \\
\hline
\end{tabular}

In each condition of in vitro development, means identified by the same letters do not differ significantly by the Scott-Knott test at $5 \%$ probability.

Table 2. Total proteins $\left[\mathrm{mg} \mathrm{g}^{-1}\right.$ (f.m.)] and proline $\left[\mu \mathrm{mol} \mathrm{g}^{-1}\right.$ (f.m.)] contents and SOD [U mg-1 (prot.)], CAT [mmol mg ${ }^{-1}$ (prot.) $\mathrm{min}^{-1}$ ], POD $\left[\mu \mathrm{mol} \mathrm{mg} \mathrm{mg}^{-1}\right.$ (prot.) $\left.\mathrm{min}^{-1}\right]$ and PPO $\left[\mu \mathrm{mol} \mathrm{mg}^{-1}\right.$ (prot.) $\mathrm{min}^{-1}$ ] activities in leaves of Pitcairnia encholirioides submitted to $0,30,42$ or 54 days of dehydration and after 90 days of rehydration, from in vitro cultivation in presence of $\mathrm{GA}_{3}$ and $30 \mathrm{~g} \mathrm{~L}^{-1}$ sucrose or NAA and $15 \mathrm{~g} \mathrm{~L}^{-1}$ sucrose. Mean \pm standard error, $\mathrm{n}=9$.

\begin{tabular}{cccccccc}
\hline \multicolumn{2}{c}{ Treatment } & Total proteins & Proline & SOD & CAT & POD & PPO \\
\hline $\mathrm{GA}_{3}$ & 0 & $0.095 \pm 0.00 \mathrm{~A}$ & $1.08 \pm 0.20 \mathrm{~A}$ & $105.6 \pm 18.2 \mathrm{~A}$ & $0.64 \pm 0.04 \mathrm{~A}$ & $87.2 \pm 2.0 \mathrm{~A}$ & $58.3 \pm 2.6 \mathrm{~A}$ \\
$30 \mathrm{~g} \mathrm{~L}^{-1}$ & 30 & $0.102 \pm 0.00 \mathrm{~A}$ & $1.21 \pm 0.24 \mathrm{~A}$ & $110.2 \pm 6.2 \mathrm{~A}$ & $0.66 \pm 0.03 \mathrm{~A}$ & $82.5 \pm 2.8 \mathrm{~A}$ & $58.5 \pm 2.7 \mathrm{~A}$ \\
& 42 & $0.099 \pm 0.00 \mathrm{~A}$ & $1.23 \pm 0.19 \mathrm{~A}$ & $102.3 \pm 3.6 \mathrm{~A}$ & $0.66 \pm 0.06 \mathrm{~A}$ & $85.5 \pm 3.0 \mathrm{~A}$ & $59.5 \pm 7.8 \mathrm{~A}$ \\
& 54 & $0.091 \pm 0.00 \mathrm{~A}$ & $1.18 \pm 0.30 \mathrm{~A}$ & $102.6 \pm 18.4 \mathrm{~A}$ & $0.67 \pm 0.03 \mathrm{~A}$ & $88.1 \pm 7.1 \mathrm{~A}$ & $62.2 \pm 3.1 \mathrm{~A}$ \\
$\mathrm{NAA}$ & 0 & $0.103 \pm 0.00 \mathrm{~A}$ & $1.24 \pm 0.20 \mathrm{~A}$ & $131.8 \pm 30.0 \mathrm{~A}$ & $0.60 \pm 0.08 \mathrm{~A}$ & $81.9 \pm 6.0 \mathrm{~A}$ & $45.1 \pm 2.2 \mathrm{~A}$ \\
$15 \mathrm{~g} \mathrm{~L}^{-1}$ & 30 & $0.107 \pm 0.00 \mathrm{~A}$ & $1.25 \pm 0.50 \mathrm{~A}$ & $127.6 \pm 2.4 \mathrm{~A}$ & $0.58 \pm 0.04 \mathrm{~A}$ & $84.0 \pm 5.0 \mathrm{~A}$ & $44.9 \pm 1.4 \mathrm{~A}$ \\
& 42 & $0.110 \pm 0.01 \mathrm{~A}$ & $1.16 \pm 0.17 \mathrm{~A}$ & $128.5 \pm 3.0 \mathrm{~A}$ & $0.57 \pm 0.02 \mathrm{~A}$ & $83.6 \pm 14.2 \mathrm{~A}$ & $44.8 \pm 4.4 \mathrm{~A}$ \\
& 54 & $0.113 \pm 0.00 \mathrm{~A}$ & $1.31 \pm 0.23 \mathrm{~A}$ & $126.7 \pm 7.6 \mathrm{~A}$ & $0.59 \pm 0.05 \mathrm{~A}$ & $79.6 \pm 2.3 \mathrm{~A}$ & $47.4 \pm 3.6 \mathrm{~A}$ \\
\hline
\end{tabular}

In each condition of in vitro development, means identified by the same letters do not differ significantly by the Scott-Knott test at $5 \%$ probability.

Table 3. Chlorophyll $a(\mathrm{Chl} a)\left[\mathrm{mg} \mathrm{g}^{-1}\right.$ (f.m.)], chlorophyll $b(\mathrm{Chl} b)\left[\mathrm{mg} \mathrm{g}^{-1}\right.$ (f.m.) $]$, chlorophyll $a+b(\mathrm{Chl} a+b)\left[\mathrm{mg} \mathrm{g}^{-1}\right.$ (f.m.) $]$ and carotenoids (Carot) $\left[\mathrm{mg} \mathrm{g}^{-1}\right.$ (f.m.)] contents, chlorophyll $a / b$ ratio $(\mathrm{Chl} a / b)$ and chlorophyll $a+b /$ carotenoids ratio (Chl $a+b /$ Carot) in leaves of Pitcairnia encholirioides after 0, 30, 42 or 54 days of dehydration, from in vitro cultivation in presence of $\mathrm{GA}_{3}$ and $30 \mathrm{~g} \mathrm{~L}^{-1}$ sucrose or NAA and $15 \mathrm{~g} \mathrm{~L}^{-1}$ sucrose. Mean \pm standard error, $\mathrm{n}=9$.

\begin{tabular}{cccccccc}
\multicolumn{2}{c}{ Treatment } & Chl $\boldsymbol{a}$ & $\mathbf{C h l} \boldsymbol{b}$ & $\mathbf{C h l} \boldsymbol{a}+\boldsymbol{b}$ & Carot & Chl $\boldsymbol{a} / \boldsymbol{b}$ & Chl $\boldsymbol{a}+\boldsymbol{b} / \mathbf{C a r o t}$ \\
\hline $\mathrm{GA}_{3}$ & 0 & $0.45 \pm 0.04 \mathrm{~B}$ & $0.19 \pm 0.02 \mathrm{~B}$ & $0.64 \pm 0.06 \mathrm{~B}$ & $0.14 \pm 0.01 \mathrm{~B}$ & $2.38 \pm 0.03 \mathrm{~A}$ & $4.34 \pm 0.08 \mathrm{~A}$ \\
$30 \mathrm{~g} \mathrm{~L}^{-1}$ & 30 & $0.47 \pm 0.02 \mathrm{~B}$ & $0.19 \pm 0.01 \mathrm{~B}$ & $0.66 \pm 0.03 \mathrm{~B}$ & $0.15 \pm 0.00 \mathrm{~B}$ & $2.40 \pm 0.02 \mathrm{~A}$ & $4.38 \pm 0.04 \mathrm{~A}$ \\
& 42 & $0.89 \pm 0.02 \mathrm{~A}$ & $0.40 \pm 0.01 \mathrm{~A}$ & $1.29 \pm 0.03 \mathrm{~A}$ & $0.33 \pm 0.01 \mathrm{~A}$ & $2.19 \pm 0.03 \mathrm{~B}$ & $3.87 \pm 0.03 \mathrm{~B}$ \\
& 54 & $1.02 \pm 0.07 \mathrm{~A}$ & $0.47 \pm 0.03 \mathrm{~A}$ & $1.49 \pm 0.10 \mathrm{~A}$ & $0.38 \pm 0.02 \mathrm{~A}$ & $2.16 \pm 0.02 \mathrm{~B}$ & $3.88 \pm 0.05 \mathrm{~B}$ \\
$\mathrm{NAA}$ & 0 & $0.38 \pm 0.02 \mathrm{C}$ & $0.16 \pm 0.01 \mathrm{C}$ & $0.54 \pm 0.03 \mathrm{C}$ & $0.12 \pm 0.00 \mathrm{D}$ & $2.36 \pm 0.00 \mathrm{~A}$ & $4.56 \pm 0.00 \mathrm{~A}$ \\
$15 \mathrm{~g} \mathrm{~L}^{-1}$ & 30 & $0.73 \pm 0.07 \mathrm{~A}$ & $0.34 \pm 0.02 \mathrm{~A}$ & $1.07 \pm 0.10 \mathrm{~A}$ & $0.28 \pm 0.01 \mathrm{~A}$ & $2.11 \pm 0.07 \mathrm{~B}$ & $3.78 \pm 0.16 \mathrm{~B}$ \\
& 42 & $0.48 \pm 0.00 \mathrm{~B}$ & $0.23 \pm 0.00 \mathrm{~B}$ & $0.71 \pm 0.00 \mathrm{~B}$ & $0.17 \pm 0.00 \mathrm{C}$ & $2.12 \pm 0.01 \mathrm{~B}$ & $4.15 \pm 0.14 \mathrm{~B}$ \\
& 54 & $0.69 \pm 0.02 \mathrm{~A}$ & $0.33 \pm 0.01 \mathrm{~A}$ & $1.02 \pm 0.03 \mathrm{~A}$ & $0.25 \pm 0.00 \mathrm{~B}$ & $2.09 \pm 0.00 \mathrm{~B}$ & $4.00 \pm 0.10 \mathrm{~B}$
\end{tabular}

In each condition of in vitro development, means identified by the same letters do not differ significantly by the Scott-Knott test at $5 \%$ probability. 
(Table 3). The results found for the other treatment varied in response to the duration of water stress.

After rehydration, the Chl $a$ content showed significant changes only in plants from a culture medium supplemented with NAA and $15 \mathrm{~g} \mathrm{~L}^{-1}$ sucrose and subjected to 54 days of water stress, with values $23 \%$ higher than the control (Table 4). Leaves from plants previously grown in the presence of $30 \mathrm{~g} \mathrm{~L}^{-1}$ sucrose and $\mathrm{GA}_{3}$, under drought, showed levels of $\mathrm{Chl} b 46.6 \%$ higher than the control, on average. For the other treatment, results showed a substantial variation. The Chl $a+b$ and Carot contents only showed significant differences in plants from culture media supplemented with $15 \mathrm{~g} \mathrm{~L}^{-1}$ sucrose and NAA and subjected to 54 days of drought stress, with values $24.8 \%$ and $28.8 \%$ higher than respective controls.

The Chl $a / b$ and Chl $a+b /$ Carot ratios showed a slight reduction in response to extension of the dehydration period, regardless of treatment (Table 3). After 42 and 54 days of stress, plants previously maintained in the presence of $30 \mathrm{~g} \mathrm{~L}^{-1}$ sucrose and $\mathrm{GA}_{3}$ showed an average reduction of $11.1 \%$ for both the ratios. For plants from media supplemented with $15 \mathrm{~g} \mathrm{~L}^{-1}$ sucrose and NAA, the average reduction was $12.6 \%$, from control until the 54th day of water stress. After rehydration, in general, the values found in treatments under water deficit were significantly different from those found in the control group, except for the $\mathrm{Chl} a+b$ /Carot ratio in plants from culture media previously supplemented with the lowest concentration of sucrose and NAA (Table 4). For the other treatment, the results showed diverse trends.

Concerning the carbohydrates, the TSS and RS contents had average increases of 46.5 and $50 \%$, respectively, from 0 to 54 days of dehydration, regardless of the previous in vitro treatment (Table 5). There was also an increase in the sucrose content after 54 days of water stress in plants from the highest concentration of sucrose and $\mathrm{GA}_{3}$. In plants from media with the lower concentration of sucrose and NAA, all the results differed significantly from the control. For starch level, differences were only found in response to the extension of dehydration in plants previously in vitro cultured in presence of NAA and $15 \mathrm{~g} \mathrm{~L}^{-1}$ sucrose, reaching $112.4 \%$ compared to the control after 42 and especially after 54 days of water stress. After rehydration, the TSS, sucrose, RS and starch in plants subjected to water stress returned to the levels found in the controls (Table 6).

Table 4. Chlorophyll $a(\mathrm{Chl} a)\left[\mathrm{mg} \mathrm{g}^{-1}\right.$ (f.m.) $]$, chlorophyll $b(\mathrm{Chl} b)\left[\mathrm{mg} \mathrm{g}^{-1}\right.$ (f.m.) $]$, chlorophyll $a+b(\mathrm{Chl} a+b)\left[\mathrm{mg} \mathrm{g}^{-1}\right.$ (f.m.) $]$ and carotenoids (Carot) $\left[\mathrm{mg} \mathrm{g}^{-1}\right.$ (f.m.) ] contents, chlorophyll $a / b$ ratio $(\mathrm{Chl} a / b)$ and chlorophyll $a+b /$ carotenoids ratio (Chl $a+b$ /Carot) in leaves of Pitcairnia encholirioides submitted to 0, 30, 42 or 54 days of dehydration and after 90 days of rehydration, from in vitro cultivation in presence of $\mathrm{GA}_{3}$ and $30 \mathrm{~g} \mathrm{~L}^{-1}$ sucrose or NAA and $15 \mathrm{~g} \mathrm{~L}^{-1}$ sucrose. Mean \pm standard error, $\mathrm{n}=9$.

\begin{tabular}{cccccccc}
\hline \multicolumn{2}{c}{ Treatment } & Chl $\boldsymbol{a}$ & $\mathbf{C h l} \boldsymbol{b}$ & $\mathbf{C h l} \boldsymbol{a}+\boldsymbol{b}$ & Carot & Chl $\boldsymbol{a} / \boldsymbol{b}$ & Chl $\boldsymbol{a}+\boldsymbol{b} / \mathbf{C a r o t}$ \\
\hline $\mathrm{GA}_{3}$ & 0 & $0.39 \pm 0.02 \mathrm{~A}$ & $0.15 \pm 0.01 \mathrm{~B}$ & $0.54 \pm 0.03 \mathrm{~A}$ & $0.13 \pm 0.00 \mathrm{~A}$ & $2.52 \pm 0.01 \mathrm{~A}$ & $4.19 \pm 0.02 \mathrm{C}$ \\
$30 \mathrm{~g} \mathrm{~L}^{-1}$ & 30 & $0.47 \pm 0.01 \mathrm{~A}$ & $0.20 \pm 0.00 \mathrm{~A}$ & $0.67 \pm 0.03 \mathrm{~A}$ & $0.15 \pm 0.00 \mathrm{~A}$ & $2.35 \pm 0.01 \mathrm{~B}$ & $4.33 \pm 0.04 \mathrm{~B}$ \\
& 42 & $0.51 \pm 0.10 \mathrm{~A}$ & $0.22 \pm 0.05 \mathrm{~A}$ & $0.73 \pm 0.15 \mathrm{~A}$ & $0.16 \pm 0.03 \mathrm{~A}$ & $2.33 \pm 0.04 \mathrm{~B}$ & $4.50 \pm 0.02 \mathrm{~A}$ \\
& 54 & $0.58 \pm 0.01 \mathrm{~A}$ & $0.25 \pm 0.00 \mathrm{~A}$ & $0.83 \pm 0.02 \mathrm{~A}$ & $0.18 \pm 0.00 \mathrm{~A}$ & $2.34 \pm 0.04 \mathrm{~B}$ & $4.47 \pm 0.04 \mathrm{~A}$ \\
$\mathrm{NAA}$ & 0 & $0.52 \pm 0.00 \mathrm{~B}$ & $0.22 \pm 0.00 \mathrm{~B}$ & $0.75 \pm 0.00 \mathrm{~B}$ & $0.16 \pm 0.00 \mathrm{~B}$ & $2.31 \pm 0.04 \mathrm{~B}$ & $4.52 \pm 0.17 \mathrm{~A}$ \\
$15 \mathrm{~g} \mathrm{~L}^{-1}$ & 30 & $0.51 \pm 0.03 \mathrm{~B}$ & $0.20 \pm 0.01 \mathrm{C}$ & $0.71 \pm 0.04 \mathrm{~B}$ & $0.16 \pm 0.01 \mathrm{~B}$ & $2.51 \pm 0.04 \mathrm{~A}$ & $4.39 \pm 0.05 \mathrm{~A}$ \\
& 42 & $0.55 \pm 0.04 \mathrm{~B}$ & $0.25 \pm 0.02 \mathrm{~B}$ & $0.80 \pm 0.07 \mathrm{~B}$ & $0.18 \pm 0.01 \mathrm{~B}$ & $2.28 \pm 0.03 \mathrm{~B}$ & $4.49 \pm 0.04 \mathrm{~A}$ \\
& 54 & $0.65 \pm 0.00 \mathrm{~A}$ & $0.29 \pm 0.00 \mathrm{~A}$ & $0.94 \pm 0.00 \mathrm{~A}$ & $0.21 \pm 0.00 \mathrm{~A}$ & $2.20 \pm 0.05 \mathrm{C}$ & $4.48 \pm 0.11 \mathrm{~A}$ \\
\hline
\end{tabular}

In each condition of in vitro development, means identified by the same letters do not differ significantly by the Scott-Knott test at $5 \%$ probability.

Table 5. Total soluble sugars (TSS) [mg glucose $\mathrm{g}^{-1}$ (f.m.)], reducing sugars (RS) [mg glucose $\mathrm{g}^{-1}$ (f.m.)], sucrose [ $\mathrm{mg} \mathrm{g}^{-1}$ (f.m.)] and starch [mg glucose $\mathrm{g}^{-1}$ (f.m.)] contents in leaves of Pitcairnia encholirioides after 0, 30, 42 or 54 days of dehydration, from in vitro cultivation in presence of $\mathrm{GA}_{3}$ and $30 \mathrm{~g} \mathrm{~L}^{-1}$ sucrose or NAA and $15 \mathrm{~g} \mathrm{~L}^{-1}$ sucrose. Mean \pm standard error, $\mathrm{n}=9$.

\begin{tabular}{|c|c|c|c|c|c|}
\hline \multicolumn{2}{|c|}{ Treatment } & \multirow{2}{*}{$\begin{array}{c}\text { TSS } \\
25.95 \pm 0.25 \mathrm{C}\end{array}$} & \multirow{2}{*}{$\begin{array}{c}\text { RS } \\
16.30 \pm 0.48 \mathrm{C}\end{array}$} & \multirow{2}{*}{$\begin{array}{c}\text { Sucrose } \\
9.65 \pm 0.77 \mathrm{~B}\end{array}$} & \multirow{2}{*}{$\begin{array}{c}\text { Starch } \\
27.84 \pm 1.07 \mathrm{~A}\end{array}$} \\
\hline $\mathrm{GA}_{3}$ & 0 & & & & \\
\hline $30 \mathrm{~g} \mathrm{~L}^{-1}$ & 30 & $25.67 \pm 0.83 \mathrm{C}$ & $16.02 \pm 0.55 \mathrm{C}$ & $9.64 \pm 0.53 \mathrm{~B}$ & $28.02 \pm 1.70 \mathrm{~A}$ \\
\hline & 42 & $29.25 \pm 0.43 \mathrm{~B}$ & $19.79 \pm 0.53 \mathrm{~B}$ & $9.45 \pm 0.33 \mathrm{~B}$ & $28.94 \pm 0.28 \mathrm{~A}$ \\
\hline & 54 & $37.76 \pm 1.05 \mathrm{~A}$ & $28.49 \pm 1.26 \mathrm{~A}$ & $11.74 \pm 0.73 \mathrm{~A}$ & $30.27 \pm 1.12 \mathrm{~A}$ \\
\hline NAA & 0 & $27.50 \pm 1.98 \mathrm{~B}$ & $19.15 \pm 1.05 \mathrm{~B}$ & $8.35 \pm 1.10 \mathrm{~B}$ & $27.34 \pm 1.75 \mathrm{C}$ \\
\hline \multirow[t]{3}{*}{$15 \mathrm{~g} \mathrm{~L}^{-1}$} & 30 & $35.28 \pm 1.43 \mathrm{~A}$ & $23.82 \pm 1.53 \mathrm{~A}$ & $10.46 \pm 1.17 \mathrm{~A}$ & $31.45 \pm 1.16 \mathrm{C}$ \\
\hline & 42 & $36.58 \pm 2.54 \mathrm{~A}$ & $24.95 \pm 2.09 \mathrm{~A}$ & $11.63 \pm 0.10 \mathrm{~A}$ & $43.93 \pm 4.21 \mathrm{~B}$ \\
\hline & 54 & $40.64 \pm 0.68 \mathrm{~A}$ & $28.49 \pm 2.60 \mathrm{~A}$ & $12.14 \pm 0.80 \mathrm{~A}$ & $58.04 \pm 1.08 \mathrm{~A}$ \\
\hline
\end{tabular}

In each condition of in vitro development, means identified by the same letters do not differ significantly by the Scott-Knott test at $5 \%$ probability. 
Table 6. Total soluble sugars (TSS) [mg glucose $\mathrm{g}^{-1}$ (f.m.)], reducing sugars (RS) [mg glucose $\mathrm{g}^{-1}$ (f.m.)], sucrose [mg g g $^{-1}$ (f.m.) ] and starch [mg glucose $\mathrm{g}^{-1}$ (f.m.)] contents in leaves of Pitcairnia encholirioides submitted to 0, 30, 42 or 54 days of dehydration and after 90 days of rehydration, from in vitro cultivation in presence of $\mathrm{GA}_{3}$ and $30 \mathrm{~g} \mathrm{~L}^{-1}$ sucrose or NAA and $15 \mathrm{~g} \mathrm{~L}^{-1}$ sucrose. Mean \pm standard error, $\mathrm{n}=9$.

\begin{tabular}{ccrccc}
\hline Treatment & \multicolumn{1}{c}{ TSS } & RS & Sucrose & Starch \\
\hline $\mathrm{GA}_{3}$ & 0 & $7.41 \pm 0.55 \mathrm{~A}$ & $2.44 \pm 0.64 \mathrm{~A}$ & $4.97 \pm 0.20 \mathrm{~A}$ & $18.65 \pm 3.27 \mathrm{~A}$ \\
$30 \mathrm{~g} \mathrm{~L}^{-1}$ & 30 & $7.43 \pm 0.68 \mathrm{~A}$ & $2.42 \pm 0.85 \mathrm{~A}$ & $5.00 \pm 0.51 \mathrm{~A}$ & $19.04 \pm 0.61 \mathrm{~A}$ \\
& 42 & $7.67 \pm 0.36 \mathrm{~A}$ & $2.46 \pm 0.93 \mathrm{~A}$ & $5.21 \pm 0.76 \mathrm{~A}$ & $19.36 \pm 1.23 \mathrm{~A}$ \\
& 54 & $8.08 \pm 0.15 \mathrm{~A}$ & $2.49 \pm 0.17 \mathrm{~A}$ & $5.59 \pm 0.04 \mathrm{~A}$ & $19.23 \pm 0.56 \mathrm{~A}$ \\
$\mathrm{NAA}^{15 \mathrm{~g} \mathrm{~L}^{-1}}$ & 0 & $10.22 \pm 1.04 \mathrm{~A}$ & $2.93 \pm 0.85 \mathrm{~A}$ & $7.24 \pm 0.38 \mathrm{~B}$ & $25.95 \pm 0.26 \mathrm{~A}$ \\
& 30 & $10.09 \pm 0.27 \mathrm{~A}$ & $2.45 \pm 0.32 \mathrm{~A}$ & $7.64 \pm 0.33 \mathrm{~B}$ & $27.11 \pm 2.04 \mathrm{~A}$ \\
& 42 & $9.81 \pm 0.31 \mathrm{~A}$ & $1.52 \pm 0.30 \mathrm{~A}$ & $8.29 \pm 0.04 \mathrm{~A}$ & $27.46 \pm 2.03 \mathrm{~A}$ \\
& 54 & $10.03 \pm 0.51 \mathrm{~A}$ & $1.34 \pm 0.83 \mathrm{~A}$ & $8.69 \pm 0.36 \mathrm{~A}$ & $28.13 \pm 0.45 \mathrm{~A}$ \\
\hline
\end{tabular}

In each condition of in vitro development, means identified by the same letters do not differ significantly by the Scott-Knott test at $5 \%$ probability.

\section{Discussion}

Proline has specific protective effects in the adaptation of plants to water deficit (Kishor et al., 1995; Yang et al., 2015). Besides acting as an osmotic adjustment mediator, proline acts as a stabilizer of subcellular structures, as redox buffer and contributes to the stabilization of ROS scavenger enzymes, being an important constituent of cell wall proteins (Szabados and Savouré, 2010; Thapa et al., 2011; Bhaskara et al., 2015). There was a significant increase in proline accumulation in plants under dehydration developed in vitro in media containing $30 \mathrm{~g} \mathrm{~L}^{-1}$ sucrose and $\mathrm{GA}_{3}$, similar to that found with Pitcairnia albiflos Herb. (CF Resende unpublished data). In studies with Oryza sativa L. and Alternanthera philoxeroides (Mart.) Griseb. under water stress, proline accumulation was observed for 30 days in plants without irrigation (Gao et al., 2008), responses also found for woody species (Liu et al., 2011) and for Chenopodium quinoa Willd. (Bascuñán-Godoy et al., 2016) under water deficit. This accumulation occurs by the up-regulation of proline biosynthetic enzymes and down-regulation of degrading enzymes and have significant role in drought tolerance (Parida et al., 2008).

The results found after 90 days of rehydration were similar to that found with wheat (Simova-Stoilova et al., 2008), Medicago truncatula Gaertn. (Filippou et al., 2011) and Ephedra alata subsp. alenda (Stapf) Trab. (Gorai et al., 2015) subjected to different periods of water stress followed by rehydration, with a reduction in proline content in leaves that had accumulated high amounts of this amino acid. Proline catabolism is an important regulator of cellular ROS balance and can influence in numerous additional regulatory pathways (Szabados and Savouré, 2010).

In the literature, some studies mention increases in the activities of antioxidant enzymes in response to water stress, as noted for Pancratium maritimum L. (Abogadallah, 2011) and Camellia sinensis (L.) Kuntze (Liu et al., 2015). However, the enzymatic activities may fluctuate in response to the extension of water stress, increasing under moderate conditions and reducing under severe conditions (Liu et al., 2011; Habibi and Hajiboland, 2012; Ebrahimi et al., 2016), demonstrating that water stress effects on plants depend on the intensity, duration and rate of the imposed drought (Simova-Stoilova et al., 2008; Pinheiro and Chaves, 2011).

Regarding the enzymatic activities, the results demonstrated higher sensitivity of the material from in vitro culture in media supplemented with NAA and lower osmotic pressure (15 $\mathrm{g} \mathrm{L}^{-1}$ sucrose), with reduction in CAT, POD and PPO activities. This behavior, associated with the maintenance of proline contents and SOD activity suggests a more severe condition of water deficit in plants from this treatment. In comparison, proline contents and POD activity improved in plants previously in vitro cultured in media with $30 \mathrm{~g} \mathrm{~L}^{-1}$ sucrose and $\mathrm{GA}_{3}$, which can be related to drought tolerance of these plants. Studies show that exogenous glucose application enhances tolerance of plants to dehydration and heat stress by increasing the content of proline and activities of antioxidants and repressing ROS accumulation (Huang et al., 2013, 2015; Cao et al., 2015), corroborating this hypothesis. There were no differences in enzymatic activity between the materials submitted to dehydration and the control after rehydration, suggesting a high adaptability of this species to water stress conditions and recovery after the end of stress period.

Another important factor is the photosynthetic metabolism performed by $P$. encholirioides, since several bromeliads are CAM plants and stress factors, like drought, are activators of CAM pathway and simultaneously responsible for increasing in antioxidant enzymes activity (Habibi and Hajiboland, 2012). The Pitcairnia genus is described as consisting of $\mathrm{C}_{3}$ species (Benzing 2000; Pierce et al., 2002), which may be corroborated by negative net night-time $\mathrm{CO}_{2}$ assimilation of $P$. encholirioides both under water deficit conditions and in well-watered plants (CF Resende unpublished data). However, further studies are needed to highlight this issue.

Despite the reduction in the content of photosynthetic pigments being a characteristic symptom of oxidative stress (Smirnoff, 1993), specific responses are found in the literature for plants under drought. In some legumes (Ashraf and Iram, 2005) and Acrocomia aculeata (Jacq.) 
Lodd. ex Mart. (Mota and Cano, 2016), water deprivation did not change significantly the content of photosynthetic pigments. However, reductions in chlorophyll and carotenoids contents were also observed in response to water stress in different species (Parida et al., 2007; Shah et al., 2011; Chen et al., 2016). In water stressed plants of the bromeliad Guzmania monostachia var. monostachia, there was an increase in chlorophylls and carotenoid contents in the leaf top, in comparison with the well-watered control, and the relative water content did not change (Freschi et al., 2010). Although there were some differences in relation to the material, in general, we found an increase in photosynthetic pigments in plants of $P$. encholirioides under drought, when compared to the control. These results may reflect a higher production of photosynthetic pigments by P. encholirioides plants under water deficit, contributing to the maintenance of photosynthetic capacity, and not only a higher concentration of these pigments as a consequence of a decrease in relative water content.

Concerning the carbohydrates, we observed in general an increase in contents of TSS, RS, sucrose and starch with the extension of dehydration, regardless of treatment. The only exception was starch content, which did not change in plants from treatment with the highest concentration of sucrose and $\mathrm{GA}_{3}$. Even though the solute accumulation, including carbohydrates, is related to the osmotic adjustment and maintenance of cell water turgor under dry periods (Seki et al., 2007), contrasting results are found in the literature. Xu et al. (2015), working with two rice genotypes under drought conditions, observed increases in TSS levels in stressed plants when compared to the control, in one of the genotypes, and no differences were found for the other one. However, Silva et al. (2009) observed a significant reduction in TSS in four Spondias tuberosa Arruda genotypes under water deficit. Garg et al. (2001) reported a gradual increase in TSS and in RS for up to 9 days of water stress in Vigna aconitifolia (Jacq.) Maréchal, with a significant reduction in starch content. This behavior was also found for cotton submitted to water deficit (Parida et al., 2007). In olive cultivars with differential tolerance to water stress, there was accumulation of sugars related to both osmoregulation and osmoprotection of cellular components (Ennajeh et al., 2009). According to Chaves-Filho and Stacciarini-Seraphin (2001), this response may be related to the action of amylase in carbohydrate metabolism, increasing the availability of soluble sugars. However, in this study, starch content increased or remained unchanged in response to prolonged water stress, which probably result in a higher adaptive capacity of the P. encholirioides plants to water stress, possibly due to the maintenance of photosynthetic capacity of plants even under conditions of water deficit, reducing the use of this reserve for metabolism. Drought can also result in alterations in the starch/sucrose ratio, since sucrose synthesis and starch breakdown can be affected by water stress (Reddy et al., 2004).

After rehydration, the TSS, sucrose, RS and starch in plants subjected to water stress returned to the levels found in the controls, suggesting a high tolerance of P. encholirioides plants to dehydration, regardless of the source of in vitro plants. Similar results were found by Parida et al. (2007), who also observed recovery of TSS, RS and starch levels after rehydration of cotton plants subjected to water stress. In plants of Beta vulgaris L. and B. macrocarpa Guss., there were reductions, after rehydration, in levels of glucose and fructose accumulated during drought period, with the opposite behavior being observed for sucrose contents (Slama et al., 2016).

The results of this study lead us to conclude that P. encholirioides is a bromeliad species that presents a high tolerance capacity to a prolonged period of dehydration. This fact can ensure high survival rates of micropropagated plants when they are transferred to field conditions, validating this important biotechnology for the propagation of endangered species. This is the first study that addresses the responses of an endemic and endangered bromeliad under drought stress, contributing to future researches that aim to understand the ecophysiology of these plants.

\section{Acknowledgements}

We thank the Fundação de Amparo à Pesquisa de Minas Gerais (FAPEMIG) for financial support to the project (CRA-APQ-01446-08), and the Coordenação de Aperfeiçoamento de Pessoal de Nivel Superior (CAPES) for providing master's degree scholarships for the first author. This work is part of the first author's Master Degree dissertation, presented in the Programa de Pós-Graduação em Ecologia of the Federal University of Juiz de Fora (PGECOL - UFJF).

\section{References}

ABOGADALLAH, G.M., 2011. Differential regulation of photorespiratory gene expression by moderate and severe salt and drought stress in relation to oxidative stress. Plant Science, vol. 180, no. 3, pp. 540-547. http://dx.doi.org/10.1016/j. plantsci.2010.12.004. PMid:21421402.

ALVES, M., TROVÓ, T., FORZZA, R.C. and VIANA, P., 2015. Overview of the systematics and diversity of Poales in the Neotropics with emphasis on the Brazilian flora. Rodriguésia, vol. 66, no. 2, pp. 305-328. http://dx.doi.org/10.1590/2175-7860201566203.

ASHRAF, M. and IRAM, A., 2005. Drought stress induced changes in some organic substances in nodules and other plant parts of two potential legumes differing in salt tolerance. Flora, vol. 200, no. 6, pp. 535-546. http://dx.doi.org/10.1016/j.flora.2005.06.005.

BASCUÑÁN-GODOY, L., REGUERA, M., ABDEL-TAWAB, Y.M. and BLUMWALD, E., 2016. Water deficit-induced changes in carbon and nitrogen partitioning in Chenopodium quinoa Willd. Planta, vol. 243, no. 3, pp. 591-603. http://dx.doi.org/10.1007/ s00425-015-2424-z. PMid:26560134.

BATES, L.S., WALDREN, R.D. and TEARE, I.D., 1973. Rapid determination of free proline for water stress studies. Plant and Soil, vol. 39, no. 1, pp. 205-207. http://dx.doi.org/10.1007/BF00018060. 
BENZING, D.H. 2000. Bromeliaceae: profile of an adaptive radiation. Cambridge: Cambridge University Press. http://dx.doi. org/10.1017/CBO9780511565175.

BHASKARA, G.B., YANG, T.H. and VERSLUES, P.E., 2015. Dynamic proline metabolism: importance and regulation in water limited environments. Frontiers in Plant Science, vol. 6, pp. 484. http://dx.doi.org/10.3389/fpls.2015.00484. PMid:26161086.

BIODIVERSITAS FOUNDATION, 2005 [viewed 23 May 2009]. Lista de espécies ameaçadas de extinção do Estado de Minas Gerais [online]. Available from: http://www.biodiversitas.org. br/cepf/edital/flora_iucn.pdf

CAO, Y.Y., YANG, M.T., CHEN, S.Y., ZHOU, Z.Q., LI, X., WANG, X.J. and BAI, J.G., 2015. Exogenous sucrose influences antioxidant enzyme activities and reduces lipid peroxidation in water-stressed cucumber leaves. Biologia Plantarum, vol. 59, no. 1, pp. 147-153. http://dx.doi.org/10.1007/s10535-014-0469-7.

CARVALHO, M.H.C., 2008. Drought stress and reactive oxygen species: production, scavenging and signaling. Plant Signaling \& Behavior, vol. 3, no. 3, pp. 156-165. http://dx.doi.org/10.4161/ psb.3.3.5536. PMid:19513210.

CHANDRA, S., BANDOPADHYAY, R., KUMAR, V. and CHANDRA, R., 2010. Acclimatization of tissue cultured plantlets: from laboratory to land. Biotechnology Letters, vol. 32, no. 9, pp. 1199-1205. http://dx.doi.org/10.1007/s10529-010-0290-0. PMid:20455074.

CHAVES-FILHO, J.T. and STACCIARINI-SERAPHIN, E., 2001. Alteração no potencial osmótico e teor de carboidratos solúveis em plantas jovens de lobeira (Solanum lycocarpum St.-Hil.) em resposta ao estresse hídrico. Revista Brasileira de Botânica $=$. Brazilian Journal of Botany, vol. 24, no. 2, pp. 199-204. http:// dx.doi.org/10.1590/S0100-84042001000200010.

CHEN, D., WANG, S., CAO, B., CAO, B., LENG, G., LI, H., YIN, L., SHAN, L. and DENG, X., 2016. Genotypic variation in growth and physiological response to drought stress and rewatering reveals the critical role of recovery in drought adaptation in maize seedlings. Frontiers in Plant Science, vol. 6, pp. 1241. http://dx.doi.org/10.3389/fpls.2015.01241. PMid:26793218.

DAL VESCO, L.L., STEFENON, V.M., WELTER, L.J., SCHERER, R.F. and GUERRA, M.P., 2011. Induction and scale-up of Billbergia zebrina nodule cluster cultures: implications for mass propagation, improvement and conservation. Scientia Horticulturae, vol. 128, no. 4, pp. 515-522. http://dx.doi. org/10.1016/j.scienta.2011.02.018

DEL LONGO, O.T., GONZÁLEZ, C.A., PASTORI, G.M. and TRIPPI, V.S., 1993. Antioxidant defenses under hyperoxygenic and hyperosmotic conditions in leaves of two lines of maize with differential sensitivity to drought. Plant \& Cell Physiology, vol. 34, no. 7, pp. 1023-1028. http://dx.doi.org/10.1093/oxfordjournals. pcp.a078515.

DINAKAR, C., DJILIANOV, D. and BARTELS, D., 2012. Photosynthesis in desiccation tolerant plants: energy metabolism and antioxidative stress defense. Plant Science, vol. 182, pp. 29-41. http://dx.doi.org/10.1016/j.plantsci.2011.01.018. PMid:22118613.

DUBOIS, M., GILLES, K.A., HAMILTON, J.K., REBERS, P.A. and SMITH, F., 1956. Colorimetric method for determination of sugars and related substances. Analytical Chemistry, vol. 28, no. 3, pp. 350-356. http://dx.doi.org/10.1021/ac60111a017.

EBRAHIMI, M., ZAMANI, G.R. and ALIZADEH, Z., 2016. Antioxidant activity: a strategy for alleviating the effects of drought on Calendula officinalis L. European Journal of Medicinal Plants, vol. 15, no. 4, pp. 1-14. http://dx.doi.org/10.9734/EJMP/2016/27035.

ENNAJEH, M., VADEL, A.M. and KHEMIRA, H., 2009. Osmoregulation and osmoprotection in the leaf cells of two olive cultivars subjected to severe water deficit. Acta Physiologiae Plantarum, vol. 31, no. 4, pp. 711-721. http://dx.doi.org/10.1007/ s11738-009-0283-6.

FILIPPOU, P., ANTONIOU, C. and FOTOPOULOS, V., 2011. Effect of drought and rewatering on the cellular status and antioxidant response of Medicago truncatula plants. Plant Signaling \& Behavior, vol. 6, no. 2, pp. 270-277. http://dx.doi. org/10.4161/psb.6.2.14633. PMid:21330785.

FORZZA, R.C., COSTA, A.F., LEME, E.M.C., VERSIEUX, L.M., WANDERLEY, M.G.L., LOUZADA, R.B., MONTEIRO, R.F., JUDICE, D.M., FERNANDEZ, E.P., BORGES, R.A.X., PENEDO, T.S.A., MONTEIRO, N.P. and MORAES, M.A., 2013. Bromeliaceae. In: G. MARTINELLI and M.A. MORAES, orgs. Livro Vermelho da Flora do Brasil. Rio de Janeiro: Andrea Jakobson Estúdio Editorial \& Jardim Botânico do Rio de Janeiro, pp. 315-396.

FOSTER, K., LAMBERS, H., REAL, D., RAMANKUTTY, P., CAWTHRAY, G.R. and RYAN, M.H., 2015. Drought resistance and recovery in mature Bituminaria bituminosa var. albomarginata. Annals of Applied Biology, vol. 166, no. 1, pp. 154-169. http:// dx.doi.org/10.1111/aab.12171.

FRESCHI, L., TAKAHASHI, C.A., CAMBUI, C.A., SEMPREBOM, T.R., CRUZ, A.B., MIOTO, P.T., MELO VERSIEUX, L., CALVENTE, A., LATANSIO-AIDAR, S.R., AIDAR, M.P.M. and MERCIER, H., 2010. Specific leaf areas of the tank bromeliad Guzmania monostachia perform distinct functions in response to water shortage. Journal of Plant Physiology, vol. 167, no. 7, pp. 526-533. http://dx.doi.org/10.1016/j.jplph.2009.10.011. PMid:19954859.

FURLAN, A., BIANUCCI, E., DEL CARMEN TORDABLE, M., KLEINERT, A., VALENTINE, A. and CASTRO, S., 2016. Dynamic responses of photosynthesis and the antioxidant system during drought and rehydration cycle in peanut plants. Functional Plant Biology, vol. 43, no. 4, pp. 337-345. http:// dx.doi.org/10.1071/FP15206.

GAO, J., XIAO, Q., DING, L., CHEN, M., YIN, L., LI, J., ZHOU, S. and HE, G., 2008. Differential responses of lipid peroxidation and antioxidants in Alternanthera philoxeroides and Oryza sativa subjected to drought stress. Plant Growth Regulation, vol. 56, no. 1, pp. 89-95. http://dx.doi.org/10.1007/s10725-008-9291-6.

GARG, B.K., KATHJU, S. and BURMAN, U., 2001. Influence of water stress on water relations, photosynthetic parameters and nitrogen metabolism of moth bean genotypes. Biologia Plantarum, vol. 44, no. 2, pp. 289-292. http://dx.doi.org/10.1023/A:1010215812791.

GORAI, M., LAAJILI, W., SANTIAGO, L.S. and NEFFATI, M., 2015. Rapid recovery of photosynthesis and water relations following soil drying and re-watering is related to the adaptation of desert shrub Ephedra alata subsp. alenda (Ephedraceae) to arid environments. Environmental and Experimental Botany, vol. 109, pp. 113-121. http://dx.doi.org/10.1016/j.envexpbot.2014.08.011.

GOUDA, E.J. and BUTCHER, D., 2016 [viewed 1 December 2016]. A list of accepted bromeliaceae names [online]. Utrecht: University Botanic Gardens. Available from: http://bromNames. florapix.nl

GOUR, V.S., SHARMA, S.K., EMMANUEL, C.J.S.K. and KANT, T., 2007. Stomata and chlorophyll content as marker 
traits for hardening of in vitro raised Balanites aegyptiaca (L.) Del. plantlets. National Academy Science Letters, vol. 30, no. $1 / 2$, pp. $45-48$.

HABIBI, G. and HAJIBOLAND, R., 2012. Comparison of photosynthesis and antioxidative protection in Sedum album and Sedum stoloniferum (Crassulaceae) under water stress. Photosynthetica, vol. 50, no. 4, pp. 508-518. http://dx.doi. org/10.1007/s11099-012-0066-y.

HAVIR, E.A. and MCHALE, N.A., 1987. Biochemical and developmental characterization of multiple forms of catalase in tobacco leaves. Plant Physiology, vol. 84, no. 2, pp. 450-455. http://dx.doi.org/10.1104/pp.84.2.450. PMid:16665461.

HOEKSTRA, F.A., GOLOVINA, E.A. and BUITINK, J., 2001. Mechanisms of plant desiccation tolerance. Trends in Plant Science, vol. 6, no. 9, pp. 431-438. http://dx.doi.org/10.1016/ S1360-1385(01)02052-0. PMid:11544133.

HONG, Y., BHATNAGAR, S. and CHANDRASEKHARAN, S. 2016. Biotechnology of tropical tree crops. In: M. Anis and N. Ahmad, eds. Plant tissue culture: propagation, conservation and crop improvement. USA: Springer, pp. 245-295. http://dx.doi. org/10.1007/978-981-10-1917-3_12.

HUANG, Y.W., NIE, Y.X., WAN, Y.Y., CHEN, S.Y., SUN, Y., WANG, X.J. and BAI, J.G., 2013. Exogenous glucose regulates activities of antioxidant enzyme, soluble acid invertase and neutral invertase and alleviates dehydration stress of cucumber seedlings. Scientia Horticulturae, vol. 162, pp. 20-30. http:// dx.doi.org/10.1016/j.scienta.2013.07.031.

HUANG, Y.W., ZHOU, Z.Q., YANG, H.X., WEI, C.X., WAN, Y.Y., WANG, X.J. and BAI, J.G., 2015. Glucose application protects chloroplast ultrastructure in heat-stressed cucumber leaves through modifying antioxidant enzyme activity. Biologia Plantarum, vol. 59, no. 1, pp. 131-138. http://dx.doi.org/10.1007/ s10535-014-0470-1.

KAR, M. and MISHRA, D., 1976. Catalase, peroxidase, and polyphenoloxidase activities during rice leaf senescence. Plant Physiology, vol. 57, no. 2, pp. 315-319. http://dx.doi.org/10.1104/ pp.57.2.315. PMid:16659474.

KISHOR, P.B.K., HONG, Z., MIAO, G.H., HU, C.A.A. and VERMA, D.P.S., 1995. Overexpression of $\Delta^{1}$-pyrroline-5carboxylate synthetase increases proline production and confers osmotolerance in transgenic plants. Plant Physiology, vol. 108, no. 4, pp. 1387-1394. http://dx.doi.org/10.1104/pp.108.4.1387. PMid:12228549.

LICHTENTHALER, H.K., 1987. Chlorophylls and carotenoids: pigments of photosynthetic biomembranes. Methods in Enzymology, vol. 148, pp. 350-382. http://dx.doi.org/10.1016/0076-6879(87)48036-1.

LIU, C., LIU, Y., GUO, K., FAN, D., LI, G., ZHENG, Y., YU, L. and YANG, R., 2011. Effect of drought on pigments, osmotic adjustment and antioxidant enzymes in six woody plant species in karst habitats of southwestern China. Environmental and Experimental Botany, vol. 71, no. 2, pp. 174-183. http://dx.doi. org/10.1016/j.envexpbot.2010.11.012.

LIU, K., ZHOU, S.B., WU, X.Y., LIU, F. and LI, G.X., 2015. Effects of irradiance on the photosynthetic traits, antioxidative enzymes, and growth of Cryptotaenia japonica. Biologia Plantarum, vol. 59, no. 3, pp. 521-528. http://dx.doi.org/10.1007/ s10535-015-0534-x.

LOWRY, O.H., ROSEBROUGH, N.J., FARR, A.L. and RANDALL, R.J., 1951. Protein measurement with the Folin phenol reagent. The Journal of Biological Chemistry, vol. 193, no. 1, pp. 265-275. PMid:14907713.

MARTINELLI, G. and FORZZA, R.C., 2006. Pitcairnia L'Hér. (Bromeliaceae): uma nova espécie, P. azouryi Martinelli \& Forzza, e observações sobre $P$. encholirioides L.B. Sm. Revista Brasileira de Botânica, vol. 29, no. 4, pp. 603-607. http://dx.doi. org/10.1590/S0100-84042006000400010.

MOHAMMADKHANI, N. and HEIDARI, R., 2008. Droughtinduced accumulation of soluble sugars and proline in two maize varieties. World Applied Sciences Journal, vol. 3, no. 3, pp. 448-453.

MOLINARI, H.B.C., MARUR, C.J., DAROS, E., CAMPOS, M.K.F., CARVALHO, J.R.F.P., BESPALHOK-FILHO, J.C., PEREIRA, L.F.P. and VIEIRA, L.G.E., 2007. Evaluation of the stress-inducible production of proline in transgenic sugarcane (Saccharum spp.): osmotic adjustment, chlorophyll fluorescence and oxidative stress. Physiologia Plantarum, vol. 130, no. 2, pp. 218-229. http://dx.doi.org/10.1111/j.1399-3054.2007.00909.x.

MOTA, C.S. and CANO, M.A.O., 2016. Respostas fisiológicas de plantas jovens de macaúba a condições de seca cíclica. Pesquisa Florestal Brasileira, vol. 36, no. 87, pp. 225-234. http://dx.doi. org/10.4336/2016.pfb.36.87.1061.

MURASHIGE, T. and SKOOG, F., 1962. A revised medium for rapid growth and bioassay with tobacco tissue cultures. Physiologia Plantarum, vol. 15, no. 3, pp. 473-497. http://dx.doi. org/10.1111/j.1399-3054.1962.tb08052.x.

NEGRELLE, R.R.B., ANACLETO, A. and MITCHELL, D., 2012. Bromeliad ornamental species: conservation issues and challenges related to commercialization. Acta Scientiarum. Biological Sciences, vol. 34, no. 1, pp. 91-100. http://dx.doi. org/10.4025/actascibiolsci.v34i1.7314.

NOCTOR, G., MHANDI, A. and FOYER, C.H., 2014. The roles of reactive oxygen metabolism in drought: not so cut and dried. Plant Physiology, vol. 164, no. 4, pp. 1636-1648. http:// dx.doi.org/10.1104/pp.113.233478.

PARIDA, A.K., DAGAONKAR, V.S., PHALAK, M.S. and AURANGABADKAR, L.P., 2008. Differential responses of enzymes involved in proline biosynthesis and degradation in drought tolerant and sensitive cotton genotypes during drought stress and recovery. Acta Physiologiae Plantarum, vol. 30, no. 5, pp. 619-627. http://dx.doi.org/10.1007/s11738-008-0157-3.

PARIDA, A.K., DAGAONKAR, V.S., PHALAK, M.S., UMALKAR, G.V. and AURANGABADKAR, L.P., 2007. Alterations in photosynthetic pigments, protein and osmotic components in cotton genotypes subjected to short-term drought stress followed by recovery. Plant Biotechnology Reports, vol. 1, no. 1, pp. 37-48. http://dx.doi.org/10.1007/s11816-006-0004-1.

PEREIRA, A.R., PEREIRA, T.S., RODRIGUES, A.S. and ANDRADE, A.C.S., 2008. Morfologia de sementes e do desenvolvimento pós-seminal de espécies de Bromeliaceae. Acta Botanica Brasilica, vol. 22, no. 4, pp. 1150-1162. http://dx.doi. org/10.1590/S0102-33062008000400026.

PIERCE, S., WINTER, K. and GRIFFITHS, H., 2002. Carbon isotope ratio and the extent of daily CAM use by Bromeliaceae. The New Phytologist, vol. 156, no. 1, pp. 75-83. http://dx.doi. org/10.1046/j.1469-8137.2002.00489.x.

PINHEIRO, C. and CHAVES, M.M., 2011. Photosynthesis and drought: can we make metabolic connections from available data? Journal of Experimental Botany, vol. 62, no. 3, pp. 869-882. http:// dx.doi.org/10.1093/jxb/erq340. PMid:21172816. 
POSPÍŠILOVÁ, J., HAISEL, D., SYNKOVÁ, H. and BAŤKOVÁ-SPOUSTOVÁ, P., 2009. Improvement of ex vitro transfer of tobacco plantlets by addition of abscisic acid to the last subculture. Biologia Plantarum, vol. 53, no. 4, pp. 617-624. http://dx.doi.org/10.1007/s10535-009-0113-0.

POSPÍŠILOVÁ, J., SYNKOVÁ, H., HAISEL, D. and SEMORÁDOVÁ, Š., 2007. Acclimation of plantlets to ex vitro conditions: effects of air humidity, irradiance, $\mathrm{CO} 2$ concentration and abscisic acid. Acta Horticulturae, vol. 748, pp. 29-38. http:// dx.doi.org/10.17660/actahortic.2007.748.2.

REDDY, A.R., CHAITANYA, K.V. and VIVEKANANDAN, M., 2004. Drought-induced responses of photosynthesis and antioxidant metabolism in higher plants. Journal of Plant Physiology, vol. 161, no. 11, pp. 1189-1202. http://dx.doi.org/10.1016/j. jplph.2004.01.013. PMid:15602811.

RESENDE, C.F., RIBEIRO, C., MENDES, G.C., SOARES, C.Q.G., BRAGA, V.F., CRUZ, B.P., FORZZA, R.C. and PEIXOTO, P.H.P., 2016a. In vitro culture of Vriesea cacuminis L.B. Sm. (Bromeliaceae): an endemic species of Ibitipoca State Park, MG, Brazil. Iheringia, vol. 71, no. 1, pp. 55-61.

RESENDE, C.F., BRAGA, V.F., PEREIRA, P.F., SILVA, C.J., VALE, V.F., BIANCHETTI, R.E., FORZZA, R.C., RIBEIRO, C. and PEIXOTO, P.H.P., 2016b. Proline levels, oxidative metabolism and photosynthetic pigments during in vitro growth and acclimatization of Pitcairnia encholirioides L.B. Sm. (Bromeliaceae). Brazilian Journal of Biology $=$ Revista Brasileira de Biologia, vol. 76, no. 1, pp. 218-227. http://dx.doi. org/10.1590/1519-6984.19314. PMid:26909639.

SÁEZ, P.L., BRAVO, L.A., SÁNCHEZ-OLATE, M., BRAVO, P.B. and RÍOS, D.G., 2016. Effect of photon flux density and exogenous sucrose on the photosynthetic performance during in vitro culture of Castanea sativa. American Journal of Plant Sciences, vol. 7, no. 14, pp. 2087-2105. http://dx.doi.org/10.4236/ ajps.2016.714187.

SALEHI-LISAR, S.Y. and BAKHSHAYESHAN-AGDAM, H. 2016. Drought stress in plants: causes, consequences, and tolerance. In: M.A. HOSSAIN, S.H. WANI, S. BHATTACHARJEE, D.J. BURRITT and L.S.P. TRAN, eds. Drought stress tolerance in plants. New York: Springer International Publishing, vol. 1 - Physiology and Biochemistry, pp. 1-16. http://dx.doi.org/10.1007/978-3319-28899-4 1 .

SEKI, M., UMEZAWA, T., URANO, K. and SHINOZAKI, K., 2007. Regulatory metabolic networks in drought stress responses. Current Opinion in Plant Biology, vol. 10, no. 3, pp. 296-302. http://dx.doi.org/10.1016/j.pbi.2007.04.014. PMid:17468040.

SHAH, A.R., KHAN, T.M., SADAQAT, H.A. and CHATHA, A.A., 2011. Alterations in leaf pigments in cotton (Gossypium hirsutum) genotypes subjected to drought stress conditions. International Journal of Agriculture and Biology, vol. 13, no. 6, pp. 902-908.

SHARMA, S., VILLAMOR, J.G. and VERSLUES, P.E., 2011. Essential role of tissue-specific proline synthesis and catabolism in growth and redox balance at low water potential. Plant Physiology, vol. 157, no. 1, pp. 292-304. http://dx.doi. org/10.1104/pp.111.183210. PMid:21791601.

SILVA, E.C., NOGUEIRA, R.J.M.C., VALE, F.H.A., MELO, M.F. and ARAÚJO, F.P., 2009. Water relations and organic solutes in four umbu tree (Spondias tuberosa) genotypes under intermittent drought. Brazilian Journal of Plant Physiology, vol. 21, no. 1, pp. 43-53. http://dx.doi.org/10.1590/S1677-04202009000100006.

SIMOVA-STOILOVA, L., DEMIREVSKA, K., PETROVA, T., TSENOV, N. and FELLER, U., 2008. Antioxidative protection in wheat varieties under severe recoverable drought at seedling stage. Plant, Soil and Environment, vol. 54, no. 12, pp. 529-536.

SLAMA, I., JDEY, A., ROUACHED, A., TALBI, O., DEBEZ, A., GHNAYA, T., LIMAMI, M.A. and ABDELLY, C., 2016. Comparative responses to water deficit stress and subsequent recovery in the cultivated beet Beta vulgaris and its wild relative B. macrocarpa. Crop \& Pasture Science, vol. 67, no. 5, pp. 553562. http://dx.doi.org/10.1071/CP15145.

SMIRNOFF, N., 1993. The role of active oxygen in the response of plants to water deficit and desiccation. The New Phytologist, vol. 125, no. 1, pp. 27-58. http://dx.doi.org/10.1111/j.1469-8137.1993. tb03863.x.

SOUZA, E.H., CARMELLO-GUERREIRO, S.M., SOUZA, F.V.D., ROSSI, M.L. and MARTINELLI, A.P., 2016. Stigma structure and receptivity in Bromeliaceae. Scientia Horticulturae, vol. 203, pp. 118-125. http://dx.doi.org/10.1016/j.scienta.2016.03.022.

SZABADOS, L. and SAVOURÉ, A., 2010. Proline: a multifunctional amino acid. Trends in Plant Science, vol. 15, no. 2, pp. 89-97. http://dx.doi.org/10.1016/j.tplants.2009.11.009. PMid:20036181.

THAPA, G., DEY, M., SAHOO, L. and PANDA, S.K., 2011. An insight into the drought stress induced alterations in plants. Biologia Plantarum, vol. 55, no. 4, pp. 603-613. http://dx.doi. org/10.1007/s10535-011-0158-8

VAN HANDEL, E., 1968. Direct microdetermination of sucrose. Analytical Biochemistry, vol. 22, no. 2, pp. 280-283. http://dx.doi. org/10.1016/0003-2697(68)90317-5. PMid:5641848.

VANHOUTTE, B., CEUSTERS, J. and DE PROFT, M.P., 2016. The 'tubing' phenomenon in commercial cultivation of Guzmania: morphology, physiology and anatomy. Scientia Horticulturae, vol. 205, pp. 112-118. http://dx.doi.org/10.1016/j.scienta.2016.04.008.

VELÁZQUEZ-MÁRQUEZ, S., CONDE-MARTÍNEZ, V., TREJO, C., DELGADO-ALVARADO, A., CARBALLO, A., SUÁREZ, R., MASCORRO, J.O. and TRUJILLO, A.R., 2015. Effects of water deficit on radicle apex elongation and solute accumulation in Zea mays L. Plant Physiology and Biochemistry, vol. 96, pp. 29-37. http://dx.doi.org/10.1016/j.plaphy.2015.07.006. PMid:26218550

XIAO, Y., NIU, G. and KOZAI, T., 2011. Development and application of photoautotrophic micropropagation plant system. Plant Cell, Tissue and Organ Culture, vol. 105, no. 2, pp. 149158. http://dx.doi.org/10.1007/s11240-010-9863-9.

XU, W., CUI, K., XU, A., NIE, L., HUANG, J. and PENG, S., 2015. Drought stress condition increases root to shoot ratio via alteration of carbohydrate partitioning and enzymatic activity in rice seedlings. Acta Physiologiae Plantarum, vol. 37, no. 2, pp. 9. http://dx.doi.org/10.1007/s11738-014-1760-0.

YANG, S.L., CHEN, K., WANG, S.S. and GONG, M., 2015. Osmoregulation as a key factor in drought hardening-induced drought tolerance in Jatropha curcas. Biologia Plantarum, vol. 59, no. 3, pp. 529-536. http://dx.doi.org/10.1007/s10535-015-0509-y. 